\title{
An Investigation Of The Impact Of Degree Of IFRS Implementation On The Comparative Accuracy And Bias Of Equity Securities Analysts East And West European Firms Earnings Forecasts
}

Arsen Djatej, Eastern Washington University, USA

Grace Gao, West Virginia University, USA

Robert H.S. Sarikas, Ohio University, USA

David L. Senteney, Ohio University, USA

\begin{abstract}
This research investigates the comparative impact of country specific degree of IFRS implementation upon the accuracy and bias of West European and East European firms equity securities analysts earnings forecasts for 29 European countries 12 of which are characterized as being East European. We utilize measures of equity securities analysts earnings forecast accuracy and bias in making comparisons of the impact of country specific degree of IFRS implementation upon the statistical properties of earnings forecasts for firms having domiciles in East European and West European countries. Our results indicate that (1) analysts earnings forecast accuracy and earning forecast bias decreases in the sense that their association with magnitudes earnings changes decreases in relation with country specific degree of implementation of IFRS and (2) the degree of reduction in analysts earnings forecast accuracy and bias is statistically more pronounced for East European firms than for West European Firms. Our results persist after controlling for cross-listing of ADRs on US securities exchanges. Bases upon this evidence we conclude that the benefits of implementation of IFRS is marginally greater for East European firms that for West European firms.
\end{abstract}

\section{INTRODUCTION}

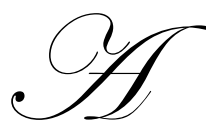

substantial body of analysts earning forecast literature documents the statistical properties - i.e., forecast accuracy and bias - for U.S. vs. non U.S. companies listed in the U.S. (e.g., Das and Saudagaran [2002 and 1998]). The literature is particularly substantial for European firms earnings forecasts. ${ }^{1}$ Furthermore, a considerable stream of related research examines the impact of differences in home country accounting standards and the utilization of IFRS (i.e, International Financial Reporting Standards) based earnings forecasts (Ashbaugh and Pincus [2001]). ${ }^{2}$

\footnotetext{
1. Beckers, Steliaros and Thomsen (2004) conducted research on Bias in European analysts' earnings forecasts. They found an optimistic bias on the part of analysts when they forecast corporate earnings of European listed companies. There findings are consistent with Capstaff, Paudyal, and Rees (1995) who found that analyst forecasts of United Kingdom firm earnings have a persistent optimism. This optimism has also been found in research on earnings forecasts of United States firms by Dreman and Berry (1995). Capstaff (1998) found this persistent optimism also for German firms.

2. Lang, Lins, and Miller [2003] investigate the impact of country-of-domicile on equity security analyst forecasts accuracy for U.S.-listed companies. Hope [2003] addresses the association between the degree of enforcement of accounting standards and
} 
We extend prior research to compare the impact of country specific degree of IFRS implementation on the accuracy and bias of analyst earnings forecast errors for East European firms as compared to West European firms. We find in our research that the degree of implementation of IFRS decreases earnings forecast accuracy and the optimistic bias of analysts earning for both East European and West European firms. However, when compared to Western European firms, the statistical impact of degree of implementation of IFRS is statistically more pronounced. We surmise that when analysts are forecasting the earnings of firms with a East European domicile, IFRS are marginally more informative for these firms than for firms having a Western European origin. In parallel, we also surmise that when analysts are forecasting the earnings of firms of Eastern European origin they are using many information sources of a Eastern European origin - which, perhaps, makes the IFRS marginally more beneficial for these firms than for West European firms. Western European information sources necessarily are influenced and even determined by the idiosyncratic characteristics of Western Europeans. Similarly Eastern European information sources necessarily are influenced and determined by the idiosyncratic characteristics of Eastern Europeans. This study makes a noteworthy contribution to the extant literature regarding the statistical properties of equity securities analysts earnings forecasts and the usefulness of IFRS by illustrating the importance of the culture contextual dimension of the usefulness of IFRS to equity securities analysts earnings forecasting task and the overall quality of disclosure comprising firms information environment.

In this next section we will review the existing literature that examines the idiosyncratic characteristics of Eastern European peoples and cultures in order to explore if there is evidence of a greater persistent optimism in Eastern Europe. This will be done to provide possible explanations of why we find a stronger optimistic bias to earnings forecasts of the earnings of Eastern European firms. Also in the next section we will provide some citations to the literature to document that the short history of the European stock markets and the many difficulties of the evolving Eastern European economic institutions might provide some measure of a logical explanation for why analysts" earnings forecasts of Eastern European firms are less accurate overall than those for Western European Firms. The second section describes the data and empirical method and research hypotheses employed in our research study. The results of the statistical models and hypotheses tests are presented and discussed in the third section of the paper. The fourth section discusses the conclusions of this research and provides some suggestions for possible future avenues of inquiry.

\section{LITERATURE REVIEW AND SOME POSSIBLE REASONS FOR OUR EMPIRICAL REGULARITIES}

We will refer to Eastern Europeans as Russians, and we will also refer to Russians as Eastern Europeans, as is often the case in the literature. We will use the terms interchangeably. Shiller, Boycko, and Korobov (1991) found in some 1990 field research that, "Soviet and American respondents were basically similar "in their attitudes toward free markets." Their field research did not directly assess Soviet optimism, but in their closing remarks it is clear that in similar circumstances they expected Russians to behave as Americans in every way. This view is consistent with Joyce (1984) who had the opinion that Russians in the Soviet period had a bleak world view only because of the harsh conditions existing in Soviet Russia.

The Soviet Union ended in 1991, and evidence of Russian optimism related to stock markets under the new and changed economic and political conditions soon burst forth. Almost simultaneously several thousand stock markets and commodity exchanges were created. Goldman (2003) observes the obvious, "That was many more than a normal market could sustain." Commenting on Russian optimism in what looks to a westerner to be very difficult or impossible circumstances, Lebaron and Carpenter (2002) offer "an old Russian saying." The saying is, "The fishing is best in troubled waters." So optimism is possible and perhaps even well-advised in the most trying of free market times.

We take note that Locus (2001) considers that the traditional Russian fatalism as the product of helplessness in influencing outcomes. The return of the market economy has given Russia back the powerful engine of the market economy. Discussing the new Russian optimism Young (1996) quotes a Russian entrepreneur who

analyst forecasts accuracy, as well as the impact of degree of accounting disclosure upon analysts forecast accuracy. 
says simply, "But all obstacles are there to be overcome." Similarly, Harper (1999) comments on the first significant marketing research done in Russia, "The response was extremely positive."

Russians are now observed profiting from accepting risk, instead of avoiding it. Blakeley (2002) worked in post-Soviet Siberia, and he opined that he thought Russian businessmen were more creative and more willing to take risks than their American counterparts. Stewart, Carland, Carland, Watson, and Sweo (2003) discovered in a controlled study that the risk propensity of United States income-focused entrepreneurs was "not significantly higher" than that of similarly focused entrepreneurs from Russia.

There is new evidence that indicates that more positive attitudes about the future are behind the developing Russian optimism. A new Public Opinion Foundation poll (2007) "found a significant change when it comes to the public's impression of the Russian economy." A Pew Global Attitudes Project from 2005 found that 45\% of Russians could be termed an optimist when, "Optimism is calculated by subtracting a respondent's current position on the ladder of life from his/her expected position five years from now." On the other hand, only $16 \%$ of Russians were considered to a pessimist. The remaining Russians were classified as neutral, or as "didn't know."

What kind of characteristics are behind the improvement of managers in Russia? De Vires, Shekshina, Korotov and Florent-Treacy (2004) found there are more and more individuals with Western business education and experience. Even those with no direct Western contact are now likely to have been exposed to Western ideas and concepts at Russian universities. Gratchev, Rogovsky, and Ratitski, (2006) have identified certain important characteristics of Russian managers in their research on leadership and culture in Russia. These positive characteristics are, "courage and ability to launch large-scale projects, decisiveness."

The increasingly prevalent Russian optimism might provide an explanation of the more positively skewed Eastern European earnings forecasts.

The difficulties and uncertainties the transitional Russian economy might explain why Eastern European firms often have less accurate earnings forecasts. Boyarshinov (2006) noted that, "Distinctive features of the Russian stock market are its short history (when compared to European markets), and its relative instability (even over such a short period of time). Also, significant is the strong vulnerability of the Russian stock market to the political situation. This is a contributor to stock market volatility. On a positive note, Smith (2003) observes that Russian tycoons now see themselves as part of a global equity market, a viewpoint he believes has revolutionary implications for the Russian economy. A fledgling market economy is likely a more difficult environment in which to forecast earnings. Nonetheless, our results are consistent with Gannon [2002, p. 129]. Blakeley (2002) observes Russians seem initially to take extreme views, and they are more comfortable with risk, and thus perhaps Russians are more enthusiastic about earnings forecasts than justified. The underlying transitional nature of the entire Russian economy as reported by Gustafson [1999] may indicate why many economic forecasts, including earnings forecasts, are problematic.

\section{IMPLEMENTATION OF INTERNATIONAL FINANCIAL REPORTING STANDARDS}

The objective of this research is to examine the impact of differential degree of implementation of IFRS on the accuracy and bias of equity securities analysts earnings forecasts for non-U.S. companies having countries of domicile characterized as being East European and West European. ${ }^{3}$ Extant research indicates that variation in countries generally accepted accounting practices impacts equity securities investors interpretation of accounting

\footnotetext{
3 . IFRS are accounting principles written by the International Accounting Standards Board (IASB) with the explicit objective of the creating a set of accounting principles utilized by business firms on an international basis and, as a result, increasing the comparability of accounting financial statements by reducing differences among countries accounting practices (i.e., Financial Accounting Standards Board [1996]). In many, if not most, cases the implementation of IFRS results in the limitation of choices within generally accepted accounting practices and increased overall disclosure by firms. A natural consequence of a reduction of choices within generally accepted accounting practices would be a more precise information set for firms implementing IFRS.
} 
communications (Alford et al. [1993]). ${ }^{4}$ But, the inverse finding does not have unambiguous empirical support in the current research literature - that is, harmonization or convergence of countries accounting practices does not necessarily imply an improved information set for equity securities investors (Joos and Lang [1994], and Auer [1996]).

This study investigates research hypotheses regarding the differential impact of countries degree of implementation of IFRS upon equity securities analysts earnings forecast accuracy ${ }^{5}$ and forecast bias ${ }^{6}$ for countries of domicile characterized as being East European and West European. Generally speaking, we expect (1) the degree of implementation of IFRS to be associated with increased forecasting task complexity as a result of reduction of opportunities for earnings smoothing, and (2) and reduce earnings forecast bias as a result of IFRS producing a uniformly more useful set of accounting principles to equity securities investors. However, the impact of IFRS depends upon existing home country accounting practices, and the degree of divergence of IFRS from existing country of domicile generally accepted accounting practices is a difficult notion to formulate concisely. ${ }^{7}$ The

4. Questions have arisen regarding the degree of enforcement of IFRS among countries (e.g., Davis-Friday and Rueschoff [1998]) as well as extent of compliance with IFRS (e.g., Street, Gray, and Bryant [1999]). The impact of changing accounting policies upon the statistical properties of equity securities analysts earnings forecasts is not unambiguous (Brown [1983]; Elliot and Philbrick [1990]). Implementation of IFRS may reduce the extent of earnings management practices among companies and, consequently, may alter the statistical properties of equity securities analysts earnings forecasts.

5. The accuracy of analysts earnings forecasts is usually assessed using the absolute value of the earnings forecast error (i.e., the absolute value of the actual earnings number minus the mean or median analysts earnings forecast). Consequently, forecast accuracy disregards whether the forecast is over or under the actual earnings number and focuses solely on the distance of the mean or median analyst forecast from the actual earnings number. A substantial body of research literature has developed identifying the economic determinants of the analysts earnings forecast error. Research results reported by DeBondt and Forbes [1999] suggests that analysts earnings forecast errors are positively related to degree of disagreement among analysts (i.e., standard deviation of analysts earnings forecasts). Sinha, Brown, and Das [1997] and Capstaff [1999] report evidence indicating that analysts earning forecast errors are negatively associated with firm size and number of analysts following firms.

6. The systematic tendency for analysts earnings forecast errors to be positive is called optimistic bias. The analysts earnings forecast error is calculated as the mean or median earnings forecast minus actual earnings. Consequently, on average analysts earnings forecasts are systematically optimistically biased. Early research such as Dreman and Berry [1995] document a statistically significant optimistic bias for concensus analysts earnings forecasts over a nearly twenty five year period. Researchers such as Capstaff, Paudyal, and Rees [1995] and Debondt and Forbes [1999] have observed similar phenomena in U.K. analysts earnings forecasts, while Capstaff et al. [1995] and Capstaff [2001] provide empirical results for Germany and the broader European region respectively. Based upon the existing literature it is somewhat accepted as a stylized fact that analysts for U.K. and Netherlands companies tend to outperform analysts earnings forecasts for Spanish and Italian companies. However, evidence regarding the comparative earnings forecasting performance of equities securities analysts in different countries remains limited.

Extant literature comprised of research such as Huberts and Fuller [1995] and DeBondt and Forbes [1999] suggests that analysts systematic optimistic bias is positively related to earnings variability. Research such as Das, Levine, and Sivaraniakrishnan [1998] indicates that analysts systematic optimistic bias is negatively associated with firm information environment. Francis and Philbrick [1993], Dowen [1996], Butler and Saraoglu [1999], Easterwood and Nutt [1999], provide evidence that analysts systematic optimistic bias is negatively associated with the magnitude of reported earnings. Over much of the recent history of analysts earnings forecast literature researchers have speculated that analysts systematic optimistic bias is a natural reaction to new information. DeBondt and Thaler [1990] hypothesize that security analysts over-estimate the persistent portion firms reported earnings increases resulting in earnings forecasts that are systematically optimistic. DeBondt and Thaler's "overreaction" hypothesis applies to earnings decreases as well but rather that analysts underestimate the persistence of magnitudes of earnings decreases. The combination of the overreaction to earnings increases and underreaction to earnings decreases results in analysts earnings forecasts that are on average systematically optimistic.

7. We note that firms may utilize IFRS and have very little, if any, divergence with country of domicile generally accepted accounting practices. On the other hand, implementation of IFRS may result in large deviations from country of domicile generally accepted accounting practices and, thereby, perhaps adding considerable complexity to equity securities analysts earnings forecasting tasks. Brown [1983] and Elliot and Philbrick [1990] provide compelling empirical evidence regarding changes in accounting methods for U.S. firms. 
combination of reduction in choices comprising home country generally accepted accounting practices the accompanying overall increased quality of disclosure and should result in substantially improved equity securities analysts earnings forecasts exhibiting reduced average forecast accuracy and reduced optimistic forecast bias.

Consequently, we intuitively expect the magnitude of degree of implementation of IFRS conditioned upon explicitly controlling home country accounting practices - i.e., via the East European and West European characterization - to be significantly associated with decreased equity securities analysts earnings forecast accuracy and decreased analysts earnings forecast bias. We test null form of these hypotheses using one-tailed statistical tests based upon our interpretation of the research literature regarding the impact of degree of convergence toward IFRS upon the statistical properties of equity securities analysts earnings forecast accuracy and bias.

$\mathbf{H}_{01}$ : Equity securities analysts earnings forecast accuracy and bias have no relation to country of domicile characterization as being East European or West European.

$\mathbf{H}_{\mathbf{0 2}}$ : $\quad$ Equity securities analysts earnings forecast error accuracy and bias has no relation to country specific degree of implementation of International Financial Reporting Standards.

$\mathbf{H}_{03}$ : There is no difference association between equity securities analysts earnings forecast error accuracy and bias and country specific degree of implementation of International Financial Reporting Standards between East European and West European firms.

\section{RESEARCH DESIGN AND EMPIRICAL METHOD}

The research design utilized in this research identifies non U.S. country of domicile firms from the 2003 Investment Brokers Estimate Service International Detail database. We employ firms having non-missing annual earnings forecasts and historical earnings data for years 1999-2002 for firms domiciled in 29 countries from the European continent geographic region. The distribution of the 29 IBES firm country of domicile over the East European and West European geographic regions is shown in Table 1. Table No. 2 shows the distribution of the sample firms individually across the Eastern Europe and Western Europe geographic regions.

The purpose the this research study is to describe the impact of degree of country of domicile IFRS implementation upon the statistical properties of equity securities analysts earnings forecasts for firms across European countries of domicile while controlling for differences between geographic regions characterized as Eastern Europe and Western Europe. ${ }^{8}$ We utilize a variation of the traditional rational expectations earnings forecast model wherein the current period earnings forecast error is dependent upon the current period earnings change (i.e., a random walk earnings expectation). As a result, the dependent variable utilized in this research study is analysts earnings forecast error which takes two forms as in the extant research literature: ${ }^{9}$

- Forecast Accuracy [Region] $]_{i}$ : Forecast Accuracy is the absolute value of the earnings forecast error, and;

- Forecast Bias [Region] ${ }_{i}$ : Forecast Bias is the algebraic signed value of the earnings forecast error.

\footnotetext{
8. In this research study we utilize country of domicile specific pervasiveness of IFRS implementation measures for East European and West European countries obtained from the Deloite and Touche IASPlus website. The IASPlus website maintains a listing of 144 countries and rates their degree of implementation of IFRS as follows:

- IFRS Not Permitted For Domestic Listed Companies (assigned value of 0);

- IFRS Permitted For Domestic Listed Companies (assigned value of 1);

- IFRS Required For Some Domestic Listed Companies (assigned value of 2);

- IFRS Required For All Domestic Listed Companies (assigned value of 3).

9 . Forecast accuracy measures the distance of the analysts earnings forecast from the actual reported earnings figure and forecast bias captures the tendency for analysts earnings forecasts to be greater than zero. Consequently, this research study investigates whether analysts earnings forecasts systematically differ between East European and West European based upon differences in the tendency of analysts earnings forecasts errors to be (1) different from zero, and (2) greater than zero.
} 
Table 1

Distribution of IBES International Detail Country of Domicile Over East European and West European Geographic Regions

\begin{tabular}{lll} 
Total Europe & Western Europe & Eastern Europe \\
Austria & & Croatia \\
Belgium & Austria & Czech Republic \\
Croatia & Belgium & Estonia \\
Czech Republic & Denmark & Hungary \\
Denmark & Finland & Latvia \\
Estonia & France & Lithuania \\
Finland & Germany & Poland \\
France & Greece & Romania \\
Germany & Ireland & Russia \\
Greece & Italy & Slovakia \\
Hungary & Luxembourg & Slovenia \\
Ireland & Netherlands & Ukraine \\
Italy & Norway & \\
Latvia & Portugal & \\
Lithuania & Spain & \\
Luxembourg & Sweden & \\
Netherlands & Switzerland & \\
Norway & Turkey & \\
Poland & & \\
Portugal & & \\
Romania & & \\
Russia & & \\
Slovakia & & \\
Slovenia & & \\
Spain & & \\
Sweden & & \\
Switzerland & & \\
Turkey & & \\
Ukraine & & \\
\hline & & \\
\hline
\end{tabular}

IBES Forecasts $\quad$ Total Europe $\quad$ West Europe $\quad$ East Europe

Total Countries

Countries: 29

Countries:17

Countries:12

Table 2: Distribution of Sample Firms Over West European and East European Geographic Regions

\begin{tabular}{llll}
\hline Source & Europe & West Europe & East Europe \\
IBES & Firms: 6744 & Firms: 4892 & Firms: 1852 \\
Total & Firms: $\mathbf{6 7 4 4}$ & Firms: $\mathbf{4 8 9 2}$ & Firms: $\mathbf{1 8 5 2}$ \\
\hline
\end{tabular}

The independent variables used to explicitly control for other factors which may systematically impact the dependent variables of interest in addition to East European and West European country of domicile are described below: 
- $\quad$ Cross $_{i}$ : An integer valued qualitative variable (e.g., 0, 1) used to capture the effect of firms having cross-listed securities such as ADRs in a US securities exchange.

- $\quad$ Year $_{i}$ : An integer valued index to capture factors impacting sample countries and firms which are attributable to attributable to specific years.

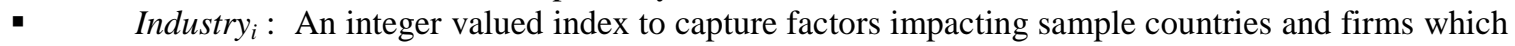
are attributable to attributable to specific industries.

- $\quad U E_{i}$ : A real valued quantitative variables taking a value equal to change in annual earnings from the previous year of the $\mathrm{i}^{\text {th }}$ European sample firm employed in this sample.

- $\quad D[\text { Region }]_{i}$ : An integer valued qualitative variable taking a value of one if the country of domicile of the $\mathrm{i}^{\text {th }}$ sample firm is uniquely from one of the former Russian republics employed in this sample and is assigned a value of zero otherwise. Research design in this manner allows for the intercept of the regression model to systematically differ between the West European and East European subsets in a manner systematically impacting the statistical results.

- $\quad X\left[\right.$ Region $_{i}:$ A real valued quantitative variable taking a value of $U E_{i}$ if the country of domicile of the $i^{\text {th }}$ sample firm is from one of the former Russian republics employed in this sample and is assigned a value of zero otherwise. Research design in this manner allows for the $U E_{i}$ slope coefficient of the regression model to systematically differ between the West European and East European subsets in a manner systematically impacting the statistical results.

- $\quad D[I A S]_{i}$ : An integer valued monotonic increasing (e.g., 0,1,2,3) index of the degree of implementation of IFRS for each sample firms country of domicile.

- X[IAS $]_{i}:$ A real valued quantitative variable taking a value of the product of the country of domicile of the $i^{\text {th }}$ sample firm degree of implementation of IFRS and the magnitude of the $i^{\text {th }}$ sample firm actual earnings change. Research design in this manner allows for the $U E_{i}$ slope coefficient of the regression model to systematically differ between the various degrees of implementation of IFRS subsets in a manner systematically impacting the statistical results - i.e., $X[I A S]_{i}:=D[I A S]_{i} x U E_{i}$

- $\quad D[\text { RegionxIAS }]_{i}$ : Integer valued interaction qualitative variable capturing the interaction between firms country of domicile degree of implementation of IAS and firms being characterized as domiciled in an East European or West European home country. The variable will take values of either zero or integer values one through four since it is measured as the product of IAS $_{i}$ and $D[\text { Region }]_{I}$ (i.e., D[Region $\left.x I A S\right]_{I}=D[I A S]_{i} x D[\text { Region }]_{I}$ ).

- X[RegionxIAS $]_{i}$ : A real valued quantitative variable taking a value of $U E_{i}$ if the country of domicile of the $\mathrm{i}^{\text {th }}$ sample firm uses the lowest level of IFRS, is monotonic increasing in relation to degree of IFRS implementation, and zero otherwise. Research design in this manner allows for the $U E_{i}$ slope coefficient of the regression model to systematically differ in relation to home country degee of implementation of IFRS. The variable is measured as the product of X[IAS $]_{i}$ and $X\left[\right.$ Region $_{I}$ (i.e., $X[\text { Region } x I A S]_{i}=I A S X[\text { Region }]_{i} x X\left[\right.$ Region $\left._{I}\right)$.

Table No.3 shows the mean and median values for each of the dependent variables employed in the empirical analyses (in absolute value and algebraic form). The data values are shown by the East European and West European geographic regions employed in the research study for comparative purposes. In addition, values of the Kruskal-Wallis Chi-Square test statistic are shown and the related probability values under the null hypothesis of the equality of means across Eastern Europe and Western Europe geographic regions. For each data variable the null hypothesis of equality of means across East European and West European geographic regions is rejected at the $\alpha=0.05$ confidence level using two-tailed Chi-Square Kruskal-Wallis tests. Consequently, we note that the data values differ significantly across Eastern Europe and Western Europe geographic regions employed in this research study. 
Table 3

Descriptive Statistics for IBES Country Of Domicile Analysts Earnings Forecasts Data By Five Geographic Regions

\begin{tabular}{l|l|l|l|l}
\multicolumn{1}{c|}{ Data/Region } & \multicolumn{1}{c}{ All Europe } & \multicolumn{1}{c}{ West Europe } & \multicolumn{1}{c}{ East Europe } & \multicolumn{1}{c}{ KW Chi Square } \\
\hline Accuracy $:$ Mean & 0.69876 & 0.7101917 & 0.5271744 & 24.9696 \\
Median & 0.30625 & 0.3125000 & 0.2203150 & $0.0001^{\dagger}$ \\
$\mathrm{N}$ & 11367 & 10657 & 710 & 16.0584 \\
\hline Bias: Mean & -0.50833 & -0.5201358 & -0.3311708 & $0.0001^{\dagger}$ \\
Median & -0.14141 & -0.1507660 & -0.0744420 & \\
$\mathrm{~N}$ & 11367 & 10657 & 710 & 0.4969 \\
UE[Alg] $]_{\mathrm{i}}$ : Mean & -0.22918 & -0.2307055 & -0.2049606 & 0.4808 \\
Median & 0.06624 & 0.0675415 & 0.0393385 & \\
$\mathrm{~N}$ & 11704 & 11010 & 694 & 0.0471 \\
$\mathrm{UE}[\mathrm{Abs}]_{\mathrm{i}}:$ Mean & 0.7507628 & 0.7513998 & 0.7406571 & 0.8282 \\
Median & 0.4137930 & 0.4137930 & 0.4104170 & \\
$\mathrm{~N}$ & 11704 & 11010 & 694 & \\
\hline
\end{tabular}

${ }^{\dagger}$ : Implicit null hypothesis that the particular variables are equal across geographic regions is rejected at the $\alpha=0.05$ confidence level using two-tailed Chi-Square Kruskal-Wallis tests. Values of the Kruskal-Wallis Chi-Square test statistic are shown and the related probability values are indicated directly below.

The dependent and independent control variables discussed previously are employed in regression analyses designed to assessing systematic differences in the statistical association between analysts earnings forecast error and forecast bias and actual earnings changes for European countries of domicile between Eastern Europe and Western Europe. Analysts earnings forecast error and forecast bias appear as dependent variables in two regression equations. Each of the two regression equations is analyzed using three specifications integrating Eastern Europe and Western Europe country of domicile parameter estimation constraints in order to illustrate the sensitivity of the results to specification.

Model (1) through Model (3) utilize analysts earnings forecast accuracy as the dependent variable and are shown immediately below. For Model (1) both the intercept and earnings change slope coefficients are constrained to varying across Eastern Europe and Western Europe country of domicile geographic regions without regard to country specific degree of IFRS implementation. For Model (2) the intercept are constrained to varying only in relation to country specific degree of IFRS implementation without regard to the Eastern Europe and Western Europe country of domicile geographic region characterization. For Model (3) both the intercept and earnings change slope coefficients are allowed to vary between both Eastern Europe and Western Europe country of domicile geographic regions and country specific degree of IFRS implementation.

Model (1) Geographic Region - East Europe and West Europe: $H_{01}: a_{5}=0 a_{6}=0$ at $\alpha=0.05$ confidence level (Two-Tailed t-Test).

Forecast Accuracy ${ }_{i}=a_{0}+a_{1} \cdot$ Cross $_{i}+a_{2} \cdot$ Year $_{i}+a_{3} \cdot$ Industry $_{i}+$

$$
+a_{4} \cdot U E_{i}+a_{5} \cdot D[\text { Region }]_{i}+a_{6} \cdot X\left[\text { Region }_{i}+v_{i}\right.
$$

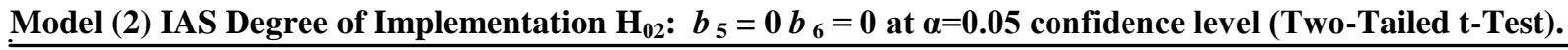

Forecast Accuracy $y_{i}=b_{0}+a_{1} \cdot$ Cross $_{i}+b_{2} \cdot$ Year $_{i}+b_{3} \cdot$ Industry $_{i}+$

$$
+b_{4} \cdot U E_{i}+b_{5} \cdot D[I A S]_{i}+b_{6} \cdot X[I A S]_{i}+v_{i}
$$


Model (3) Geographic Region and IAS Interaction $\mathrm{H}_{03}: c_{9}=0 c_{10}=0$ at $\alpha=0.05$ confidence level (Two-Tailed t-Test).

$$
\begin{aligned}
\text { Forecast Accuracy }_{i}= & c_{0}+c_{1} \cdot \text { Cross }_{i}+c_{2} \cdot \text { Year }_{i}+c_{3} \cdot \text { Industry }_{i}+c_{4} \cdot U E_{i} \\
& +c_{5} \cdot \text { D }\left[\text { Region }_{i}+c_{6} \cdot X[\text { Region }]_{i}\right. \\
& +c_{7} \cdot D[\text { IAS }]_{i}+c_{8} \cdot X[\text { IAS }]_{i} \\
& \left.+c_{9} \cdot \text { D[Region }\right]_{i} \cdot D[\text { IAS }]_{i}+c_{10} \cdot X[\text { Region }]_{i} \cdot X[I A S]_{i}+w_{i}
\end{aligned}
$$

Across the three regression specifications the coefficients of primary interest pertain to the differential magnitude of forecast accuracy and the degree of association between magnitudes of earnings changes and earnings forecast accuracy (i.e., $\mathrm{a}_{6}, \mathrm{~b}_{6}$, and $\mathrm{c}_{10}$ ) and in all cases the significance of the coefficient is statistically tested using two-tailed hypotheses tests of the null hypothesis that the coefficient is equal to zero. If the null hypothesis is rejected the result provides an indication that analysts earnings forecast accuracy is larger or smaller (i.e., depending on whether the estimated coefficient is greater than zero or less than zero) between East European and West European countries of domicile, country specific degree of IFRS implementation, and their interaction.

Model (4) through Model (6) utilize analysts earnings forecast bias as the dependent variable and are shown immediately below. In Model (4) both of the regression intercept and earnings change slope coefficients are not required to be equal between Eastern Europe and Western Europe geographic regions. For Model (5) both of the regression intercept and earnings change slope coefficients are allowed to vary in relation to country specific degree of IFRS implementation. In Model (6) both the intercept and earnings change slope coefficients are allowed to take different values over both Eastern Europe and Western Europe geographic regions, country specific degree of IFRS implementation, as well as their interaction.

In these regression specifications the coefficient of primary interest pertains to systematic differences in the magnitude of earnings forecast bias and degree of association of earnings forecast bias with earnings changes (i.e., $\mathrm{a}_{6}, \mathrm{~b}_{6}$, and $\mathrm{c}_{10}$ ) between Eastern Europe and Western Europe geographic regions, country specific degree of IFRS implementation, as well as their interaction, and in all cases the significance of the coefficient is statistically tested using two-tailed hypotheses tests of the null hypothesis that the coefficient is equal to zero. Rejecting the null hypothesis provides an indication that analysts earnings forecast bias is either larger or smaller (i.e., is either more or less associated with the tendency of earnings forecast errors to be greater than zero) in relation to country of domicile Eastern Europe and Western Europe geographic regions, country specific degree of IFRS implementation, and their interaction.

Model (4) Geographic Region - East Europe and West Europe: $\mathrm{H}_{01}: a_{5}=0 a_{6}=0$ at $\alpha=0.05$ confidence level (Two-Tailed t-Test).

Forecast Bias $_{i}=a_{0}+a_{1} \cdot$ Cross $_{i}+a_{2} \cdot$ Year $_{i}+a_{3} \cdot$ Industry $_{i}$ $+a_{4} \cdot U E_{i}+a_{5} \cdot D[\text { Region }]_{i}+a_{6} \cdot X[\text { Region }]_{i}+v_{i}$

Model (5) IAS Degree of Implementation $\mathrm{H}_{02}: b_{5}=0 b_{6}=0$ at $\alpha=0.05$ confidence level (Two-Tailed t-Test).

Forecast Bias $_{i}=b_{0}+a_{1} \cdot$ Cross $_{i}+b_{2} \cdot$ Year $_{i}+b_{3} \cdot$ Industry $_{i}$

$+b_{4} \cdot U E_{i}+b_{5} \cdot D[I A S]_{i}+b_{6} \cdot X[I A S]_{i}+v_{i}$ 
Model (6) Geographic Region and IAS Interaction $\mathrm{H}_{03}: c_{9}=0 c_{10}=0$ at $\alpha=0.05$ confidence level (Two-Tailed t-Test).

$$
\begin{aligned}
\text { Forecast Bias }_{i}= & c_{0}+c_{1} \cdot \text { Cross }_{i}+c_{2} \cdot \text { Year }_{i}+c_{3} \cdot \text { Industry }_{i}+c_{4} \cdot U E_{i} \\
& +c_{5} \cdot \text { D }\left[\text { Region }_{i}+c_{6} \cdot X[\text { Region }]_{i}\right. \\
& +c_{7} \cdot D[\text { IAS }]_{i}+c_{8} \cdot X[I A S]_{i} \\
& +c_{9} \cdot D[\text { Region }]_{i} \cdot D[I A S]_{i}+c_{10} \cdot X[\text { Region }]_{i} \cdot X[I A S]_{i}+w_{i}
\end{aligned}
$$

\section{STATISTICAL MODEL ESTIMATION AND RESULTS OF HYPOTHESIS TESTS}

Table No.4 shows the empirical model estimation and statistical results for Model (1) through Model (3) utilizing analysts earnings forecast accuracy as the dependent variable. ${ }^{10}$ The most striking result is reflected in Model (3) wherein both the East European country of domicile firms and country specific degree of implementation of IFRS reduce earnings forecast accuracy in the sense that the statistical association between magnitudes of actual earnings changes and magnitudes of earnings forecast errors decreases for these firms - indicating that a given earnings change decreases the related earnings forecast error. Both $\mathrm{H}_{01}$ and $\mathrm{H}_{02}$ are rejected at the at the $\alpha=0.05$ confidence level using two-tailed t-tests indicating that the slope qualitative variable coefficients are significantly less that zero for both the East European country of domicile firms and country specific degree of implementation of IFRS. Furthermore, $\mathrm{H}_{03}$ is rejected at the at the $\alpha=0.05$ confidence level using two-tailed t-tests indicating that the interaction of East European country of origin and degree of implementation of IFRS are jointly statistically significant. Consequently, we conclude from these statistical results that - although the overall level of analysts earnings forecasts accuracy is smaller for East European firms - the analysts have a more difficult task forecasting earnings for East European firms and is probably attributable less rapid implementation of more uniformly acceptable accounting practices such as IFRS.

10. Model adjusted R-Squares range from $29.04 \%$ for Model (1) to $29.62 \%$ for Model (3). The impact of changes in constraining the intercept and earnings change coefficients across observations for Eastern Europe and Western Europe geographic regions and degree of implementation of IFRS is a modest increase in model explanatory power. 
Table 4

Results of Cross-Sectional Analysts Earnings Forecast Accuracy Regression With And Without IAS Reporting Standards Constraints

\begin{tabular}{|c|c|c|c|}
\hline Coefficients For Independent Variables & $\begin{array}{l}\text { Model } 1: R^{2}=0.2904 \\
(D F=1,771)\end{array}$ & $\begin{array}{l}\text { Model 2: } \mathrm{R}^{2}=0.2903 \\
(\mathrm{DF}=1,771)\end{array}$ & $\begin{array}{l}\text { Model 3: } \mathrm{R}^{2}=0.2962 \\
(\mathrm{DF}=1,771)\end{array}$ \\
\hline & $\begin{array}{c}2.06966 \\
(22.86)^{\dagger}\end{array}$ & $\begin{array}{l}1.63176 \\
(16.19)^{\dagger}\end{array}$ & $\begin{array}{l}1.67151 \\
(16.59)^{\dagger}\end{array}$ \\
\hline $\operatorname{Cross}_{i}$ : Coefficient & & & \\
\hline Listing Qualitative Variable & $\begin{array}{l}-0.03078 \\
(-0.95)\end{array}$ & $\begin{array}{l}-0.06206 \\
(-1.93)\end{array}$ & $\begin{array}{l}-002402 \\
(-0.74)\end{array}$ \\
\hline Year ${ }_{i}$ : Coefficient & & & \\
\hline Annual Qualitative Variable & $\begin{array}{l}-0.11178 \\
(-20.39) \dagger\end{array}$ & $\begin{array}{l}-0.10949 \\
(-20.04)^{\dagger}\end{array}$ & $\begin{array}{l}-0.11513 \\
(-21.02)^{\dagger}\end{array}$ \\
\hline Industry $_{\mathrm{i}}$ : Coefficient & & & \\
\hline Two-Digit SIC Indicator & $\begin{array}{l}0.000062 \\
(0.17)\end{array}$ & $\begin{array}{l}-0.0000223 \\
(-0.06)\end{array}$ & $\begin{array}{l}0.0000629 \\
(0.17)\end{array}$ \\
\hline $\begin{array}{l}\mathrm{UE}_{\mathrm{i}} \text { : Coefficient } \\
\text { Earnings }\end{array}$ & $\begin{array}{l}0.58005 \\
(61.04)^{\dagger(1) \ddagger}\end{array}$ & $\begin{array}{l}0.81962 \\
(17.40)^{\dagger(2) \ddagger}\end{array}$ & $\begin{array}{l}0.86193 \\
(18.14)^{\dagger(1)}\end{array}$ \\
\hline $\begin{array}{l}\text { (a): D }[\text { Region }]_{i \mathrm{i}}: \text { Differential Coefficient } \\
\text { East Europe Unexpected Earnings } \\
\text { (b): X[Region }]_{\mathrm{i}}: \text { Differential Coefficient } \\
\text { East Europe Unexpected Earnings }\end{array}$ & $\begin{array}{l}-0.19401 \\
(-4.78)^{\dagger(1) \ddagger} \\
-0.06920 \\
(-2.00)^{\dagger(1)}\end{array}$ & $\begin{array}{l}\text { [Not Applicable] } \\
\text { [Not Applicable] }\end{array}$ & $\begin{array}{l}1.72733 \\
(3.78)^{\dagger(1) \ddagger} \\
-1.40894 \\
(-2.91)^{\dagger(1) \ddagger}\end{array}$ \\
\hline $\begin{array}{l}\text { (c): } D[I F R S]_{i \mathrm{i}}: \text { Differential Coefficient } \\
\text { Implementation of IFRS }\end{array}$ & [Not Applicable] & $\begin{array}{l}0.10812 \\
(7.90)^{\dagger(2)}\end{array}$ & $\begin{array}{l}0.12372 \\
(8.98)^{\dagger(2)}\end{array}$ \\
\hline $\begin{array}{l}\text { (d): XIFRS }]_{\mathrm{i}} \text { : Differential Coefficient } \\
\text { Implementation of IFRS }\end{array}$ & [Not Applicable] & $\begin{array}{l}-0.06665 \\
(-5.28)^{\dagger(2)}\end{array}$ & $\begin{array}{l}-0.07673 \\
(-6.02)^{\dagger(2) \ddagger}\end{array}$ \\
\hline $\begin{array}{l}\text { (e): D[RegionxIAS }]_{i}: \text { East European } \\
\text { Implementation IFRS Interaction }\end{array}$ & [Not Applicable] & [Not Applicable] & $\begin{array}{l}-050509 \\
(-4.29)^{\dagger(3) \ddagger}\end{array}$ \\
\hline $\begin{array}{l}\text { (f): X[RegionxIAS }]_{i}: \text { East European } \\
\text { Implementation IFRS Interaction }\end{array}$ & [Not Applicable] & [Not Applicable] & $\begin{array}{l}0.35514 \\
(4.36)^{\dagger(3)}\end{array}$ \\
\hline
\end{tabular}

(a): D[Region $]_{i}$ : An integer valued qualitative variable taking a value of one if the country of domicile of the $\mathrm{i}^{\text {th }}$ sample firm is uniquely from one of the former Russian republics employed in this sample and is assigned a value of zero otherwise. Research design in this manner allows for the intercept of the regression model to systematically differ between the West European and East European subsets in a manner systematically impacting the statistical results.

(b): X[Region $]_{i}$ : A real valued quantitative variable taking a value of $U E_{i}$ if the country of domicile of the $\mathrm{i}^{\text {th }}$ sample firm is from one of the former Russian republics employed in this sample and is assigned a value of zero otherwise. Research design in this manner allows for the $U E_{i}$ slope coefficient of the regression model to systematically differ between the West European and East European subsets in a manner systematically impacting the statistical results.

(c): D[IAS $]_{i}$ : An integer valued monotonic increasing (e.g., 0,1,2,3) index of the degree of implementation of IFRS for each sample firms country of domicile.

(d): $X[I A S]_{i}$ : A real valued quantitative variable taking a value of the product of the country of domicile of the $\mathrm{i}^{\text {th }}$ sample firm degree of implementation of IFRS and the magnitude of the $i^{\text {th }}$ sample firm actual earnings change. Research design in this manner allows for the $U E_{i}$ slope coefficient of the regression model to systematically differ between the various degrees of implementation of IFRS subsets in a manner systematically impacting the statistical results - i.e., $X[I A S]_{i}:=D[I A S]_{i} x U E_{i}$

(e): D[RegionxIAS $]_{i}$ : Integer valued interaction qualitative variable capturing the interaction between firms country of domicile degree of implementation of IAS and firms being characterized as domiciled in an East European or West European home country. The variable will take values of either zero or integer values one through four since it is measured as the product of IAS $i$ and $D[\text { Region }]_{I}$ (i.e., $D[\text { Region } x I A S]_{I}=D[I A S]_{i} x D[\text { Region }]_{I}$ ).

(f); X[RegionxIAS $]_{i}$ : A real valued quantitative variable taking a value of $U E_{i}$ if the country of domicile of the $\mathrm{i}^{\text {th }}$ sample firm uses the lowest level of IFRS, is monotonic increasing in relation to degree of IFRS implementation, and zero otherwise. Research design in this manner allows for the $U E_{i}$ slope coefficient of the regression model to systematically differ in relation to home country degee of implementation of IFRS. The variable is measured as the product of X[IAS $]_{i}$ and $X[\text { Region }]_{I}$ (i.e., $\left.X[\text { Region } x I A S]_{i}=I A S X[\text { Region }]_{i} \times X[\text { Region }]_{I}\right)$. 
(Table 4 Continued ...)

$\dagger$ : Null implicit null hypothesis that the coefficient is equal to zero is rejected at the $\alpha=0.05$ confidence level using two-tailed $t-$ tests. The critical t-statistic value for the two-tailed t-tests is $|t|=1.95$.

$\$$ : The specified null hypothesis (shown below) rejected at the $\alpha=0.05$ confidence level using one-tailed t-tests, two-tailed t-tests, one-tailed F-tests, or two-tailed F-tests as is appropriate in the particular circumstances. Related probability values for each test are shown parenthetically.

Model (1) Geographic Region - East Europe and West Europe: $\mathrm{H}_{01}: a_{5}=0 a_{6}=0$ at $\alpha=0.05$ confidence level (Two-Tailed t-Test).

Forecast Accuracy ${ }_{i}=a_{0}+a_{1} \cdot$ Cross $_{i}+a_{2} \cdot$ Year $_{i}+a_{3} \cdot$ Industry $_{i}+$

$$
+a_{4} \cdot U E_{i}+a_{5} \cdot D[\text { Region }]_{i}+a_{6} \cdot X[\text { Region }]_{i}+v_{i}
$$

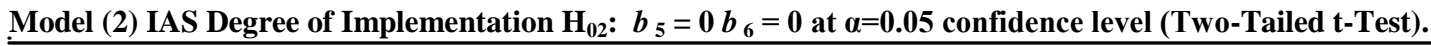

Forecast Accuracy $_{i}=b_{0}+a_{1} \cdot$ Cross $_{i}+b_{2} \cdot$ Year $_{i}+b_{3} \cdot$ Industry $_{i}+$

$+b_{4} \cdot U E_{i}+b_{5} \cdot D[I A S]_{i}+b_{6} \cdot X[I A S]_{i}+v_{i}$

Model (3) Geographic Region and IAS Interaction $\mathrm{H}_{03}: c_{9}=0 c_{10}=0$ at $\alpha=0.05$ confidence level (Two-Tailed t-Test).

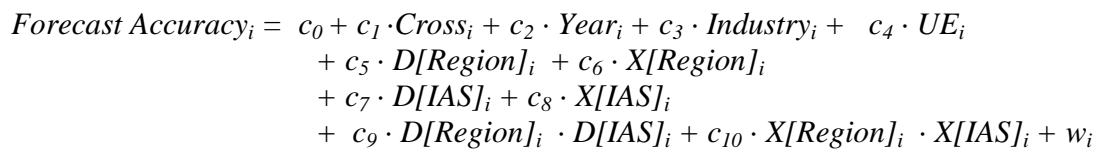

Table No.5 shows the empirical model estimation and statistical results for Model (4) through Model (6) utilizing analysts earnings forecast bias as the dependent variable. ${ }^{11}$ The particularly noteworthy result is indicated by Model (3) wherein both the East European country of domicile firms and country specific degree of implementation of IFRS reduce earnings forecast bias in the sense that the statistical relation between magnitudes of actual earnings changes and magnitudes of earnings forecast errors decreases algebraically for these firms indicating that a given earnings change decreases the tendency for the related earnings forecast error to be positive. Both $\mathrm{H}_{01}$ and $\mathrm{H}_{02}$ are rejected at the at the $\alpha=0.05$ confidence level using two-tailed t-tests indicating that the slope qualitative variable coefficients are significantly less that zero for both the East European country of domicile firms and country specific degree of implementation of IFRS. In addition, $\mathrm{H}_{03}$ is rejected at the at the $\alpha=0.05$ confidence level using two-tailed t-tests indicating that the interaction of East European country of origin and degree of implementation of IFRS are jointly statistically significant. Consequently, we conclude from these statistical results that - although the overall level of analysts earnings forecasts bias is less for East European firms - the implementation of more uniformly acceptable accounting practices such as IFRS tends to reduce the systematic optimistic bias displayed in general by equity securities analysts earnings forecasts.

11. Model adjusted R-Squares range from $27.79 \%$ for Model (4) to $28.75 \%$ for Model (6). The impact of not constraining the intercept and earnings change coefficients to the same values for all geographic regions is an increase in model explanatory power. 
Table 5

Results of Cross-Sectional Analysts Earnings Forecast Bias Regression With And Without Degree of IFRS Implementation Constraints

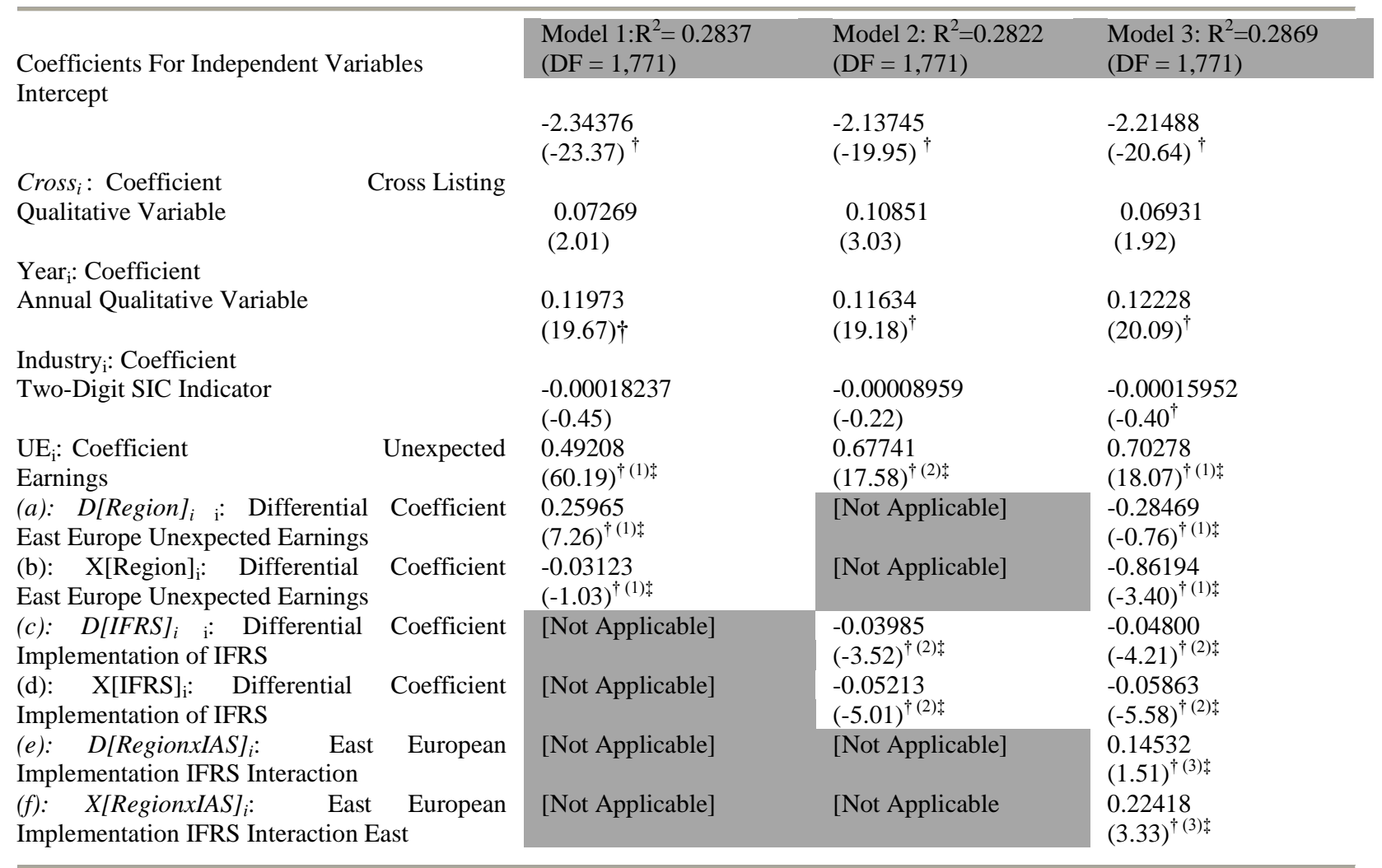

(a): D[Region $]_{i}$ : An integer valued qualitative variable taking a value of one if the country of domicile of the $\mathrm{i}^{\text {th }}$ sample firm is uniquely from one of the former Russian republics employed in this sample and is assigned a value of zero otherwise. Research design in this manner allows for the intercept of the regression model to systematically differ between the West European and East European subsets in a manner systematically impacting the statistical results.

(b): X[Region $]_{i}$ : A real valued quantitative variable taking a value of $U E_{i}$ if the country of domicile of the $\mathrm{i}^{\text {th }}$ sample firm is from one of the former Russian republics employed in this sample and is assigned a value of zero otherwise. Research design in this manner allows for the $U E_{i}$ slope coefficient of the regression model to systematically differ between the West European and East European subsets in a manner systematically impacting the statistical results.

(c): $D[I A S]_{i}$ : An integer valued monotonic increasing (e.g., 0,1,2,3) index of the degree of implementation of IFRS for each sample firms country of domicile.

(d): $X[I A S]_{i}$ : A real valued quantitative variable taking a value of the product of the country of domicile of the $\mathrm{i}^{\text {th }}$ sample firm degree of implementation of IFRS and the magnitude of the $i^{\text {th }}$ sample firm actual earnings change. Research design in this manner allows for the $U E_{i}$ slope coefficient of the regression model to systematically differ between the various degrees of implementation of IFRS subsets in a manner systematically impacting the statistical results - i.e., $X[I A S]_{i}:=D[I A S]_{i} x U E_{i}$

(e): D[RegionxIAS $]_{i}$ : Integer valued interaction qualitative variable capturing the interaction between firms country of domicile degree of implementation of IAS and firms being characterized as domiciled in an East European or West European home country. The variable will take values of either zero or integer values one through four since it is measured as the product of IAS and $D[\text { Region }]_{I}$ (i.e., $D[\text { Region } x I A S]_{I}=D[I A S]_{i} \times D[\text { Region }]_{I}$ ).

(f); X[RegionxIAS $]_{i}$ : A real valued quantitative variable taking a value of $U E_{i}$ if the country of domicile of the $\mathrm{i}^{\text {th }}$ sample firm uses the lowest level of IFRS, is monotonic increasing in relation to degree of IFRS implementation, and zero otherwise. Research design in this manner allows for the $U E_{i}$ slope coefficient of the regression model to systematically differ in relation to home country degee of implementation of IFRS. The variable is measured as the product of $\mathrm{X}[\mathrm{IAS}]_{i}$ and $X[\text { Region }]_{I}$ (i.e., $\left.X[\text { Region } x I A S]_{i}=I A S X[\text { Region }]_{i} \times X[\text { Region }]_{I}\right)$. 
(Table 5 Continued ...)

$\dagger$ : Null implicit null hypothesis that the coefficient is equal to zero is rejected at the $\alpha=0.05$ confidence level using two-tailed $t-$ tests. The critical t-statistic value for the two-tailed t-tests is $|t|=1.95$.

$\$$ : The specified null hypothesis (shown below) rejected at the $\alpha=0.05$ confidence level using one-tailed t-tests, two-tailed t-tests, one-tailed F-tests, or two-tailed F-tests as is appropriate in the particular circumstances. Related probability values for each test are shown parenthetically.

Model (4) Geographic Region - East Europe and West Europe: $H_{01}: a_{5}=0 a_{6}=0$ at $\alpha=0.05$ confidence level (Two-Tailed t-Test).

Forecast Bias $_{i}=a_{0}+a_{1} \cdot$ Cross $_{i}+a_{2} \cdot$ Year $_{i}+a_{3} \cdot$ Industry $_{i}$

$+a_{4} \cdot U E_{i}+a_{5} \cdot D[\text { Region }]_{i}+a_{6} \cdot X[\text { Region }]_{i}+v_{i}$

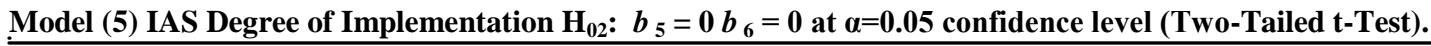

Forecast Bias $_{i}=b_{0}+a_{1} \cdot$ Cross $_{i}+b_{2} \cdot$ Year $_{i}+b_{3} \cdot$ Industry $_{i}$

$+b_{4} \cdot U E_{i}+b_{5} \cdot D[I A S]_{i}+b_{6} \cdot X[I A S]_{i}+v_{i}$

Model (6) Geographic Region and IAS Interaction $\mathrm{H}_{03}: c_{9}=0 c_{10}=0$ at $\alpha=0.05$ confidence level (Two-Tailed t-Test).

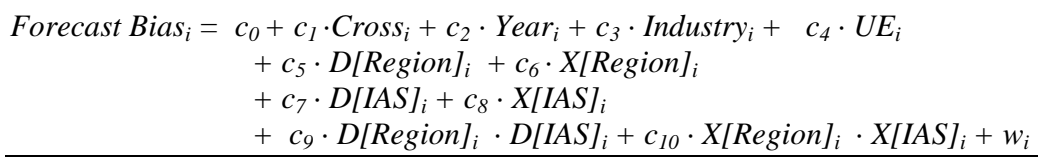

Table 6

Summary Of Forecast Accuracy Regression Models (1) - (3)

and Forecast Bias Regression Models (4) - (6) Hypotheses Tests

Figure 1 Analysts Earning Forecast Accuracy: Comparison of West European and East European Countries Of Domicile

Model/Hypothesis

Model (1)

Model (2)

Model (3)

$$
\begin{aligned}
& \text { East vs. West } \\
& \mathrm{H}_{01}: a_{6}=0
\end{aligned}
$$

Reject at the $\alpha=0.05$ confidence level (Two-Tailed t-Test).

Reject at the $\alpha=0.05$ confidence level (Two-Tailed t-Test).

Reject at the $\alpha=0.05$ confidence level (Two-Tailed t-Test).

\section{Degree IFRS}

$H_{02}: b_{6}=0$

[Not Applicable]

Reject at the $\alpha=0.05$ confidence

level (Two-Tailed t-Test). [Not Applicable]

Reject at the $\alpha=0.05$ confidence level (Two-Tailed t-Test).
Interaction $\mathbf{H}_{\mathbf{0 3}}$ : $\mathrm{c}_{9}=0$ and $c_{10}=0$

[Not Applicable]

Reject at the $\alpha=0.05$ confidence level (Two-Tailed t-Test). 
(Table 6 Continued ...)

Figure 2 Analysts Earning Forecast Bias: Comparison of West European and East European Countries Of Domicile

\begin{tabular}{|c|c|c|c|}
\hline Model/Hypothesis & $\begin{array}{l}\text { East vs. West } \\
\mathrm{H}_{01}: a_{6}=0\end{array}$ & $\begin{array}{l}\text { Degree IFRS } \\
\text { Ho2 }_{02} b_{6}=0\end{array}$ & $\begin{array}{l}\text { Interaction } \mathrm{H}_{03}: \\
c_{9}=0 \text { and } c_{10}=0\end{array}$ \\
\hline Model (4) & $\begin{array}{l}\text { Reject at the } \alpha=0.05 \\
\text { confidence level (Two-Tailed t- } \\
\text { Test). }\end{array}$ & [Not Applicable] & [Not Applicable] \\
\hline Model (5) & $\begin{array}{l}\text { Reject at the } \alpha=0.05 \\
\text { confidence level (Two-Tailed t- } \\
\text { Test). }\end{array}$ & $\begin{array}{l}\text { Reject at the } \alpha=0.05 \\
\text { confidence level (Two-Tailed t- } \\
\text { Test). }\end{array}$ & [Not Applicable] \\
\hline Model (6) & $\begin{array}{l}\text { Reject at the } \alpha=0.05 \\
\text { confidence level (Two-Tailed t- } \\
\text { Test). }\end{array}$ & $\begin{array}{l}\text { Reject at the } \alpha=0.05 \\
\text { confidence level (Two-Tailed t- } \\
\text { Test). }\end{array}$ & $\begin{array}{l}\text { Reject at the } \alpha=0.05 \\
\text { confidence level (Two-Tailed t- } \\
\text { Test). }\end{array}$ \\
\hline
\end{tabular}

\section{CONCLUSION AND SUGGESTIONS FOR FUTURE RESEARCH}

The purpose of this research is to describe the impact of country specific degree of implementation of IFRS upon analysts earnings forecast accuracy and bias for firms having countries of domicile in East Europe as compared with West Europe. We find that firms from East Europe countries have analysts earnings forecasts which display less earnings forecast accuracy and a tendency to exhibit less positive bias than firms from West Europe. We attribute the tendency for East European firms to have less accurate and less positively skewn earnings forecasts to the larger marginal benefit of former Soviet republics implementing uniformly accepted quality accounting standards such as IFRS in their particularly information environment.

\section{ACKNOWLEDGEMENTS}

The authors wish to acknowledge and thank Investment Brokers Estimate Service (IBES) ThomsonPrimark for providing the country-specific analyst earnings forecast data as part of support for a broad range of earnings forecast research

\section{REFERENCES}

1. Alford, A., J. Jones, R. Leftwich, and M. Zmijewski. 1993. The Relative Informativeness of Accounting Disclosures in Different Countries. Journal of Accounting Research (Supplement): 183-223.

2. American Institute of Certified Public Accountants. Special Committee and Creditors. New York, New York: AICPA.

3. Ashbaugh, H., and M. Pincus. 2001. Domestic Accounting Standards, International Accounting Standards, and the Predictability of Earnings. Journal of Accounting Research 39 (3):417-434.

4. Beckers, Stan, Michael Steliaros, and Alexander Thomson. 2004, Bias in European Analysts' Earnings Forecasts. Financial Analysts Journal, vol. 60, no.2, (March/April):74-85.

5. Blakely, Alexander 2002 Siberia Bound: Chasing the American Dream on Russia's Wild Frontier, Sourcebooks, Inc: Naperville, Illinois. 145

6. Boyarshinov, Andrey 2006, Comparative Analysis and Estimation of Mathematical Methods of Market Risk Valuation in Application to the Russian Stock Market. Working Paper, Society for Computational Economics - Computing in Economics and Finance 2006 - number 127. 1

7. Brown, L. 1983. Accounting Changes and the Accuracy of Analyst Earnings Forecasts. Journal of Accounting Research (Autumn): 432-43.

8. Butler, K.C., and L.L. Saraoglu. 1499. Improving Analysts' Negative Earnings Forecasts. Financial Analysts Journal, vol. 53, no. 3 (May/June);48-56. 
9. Capstaff, John, Krisbna Paudyal, and William Rees. 1995. The Accuracy and Rationality of Earnings Forecasts by UK Analysts. Journal of Business Finance and Accounting, vol. 22, no. 10 (January):67-85.

10. Capstaff, John. 1998. Analysts' Forecasts of German Firms' Earnings: A Comparitive Analysis. Journal of International Financial Management and Accounting, vol. 9, no. 2 (June):83-116.

11. Capstaff, John. 1999. The Relative Forecast Accuracy of UK Brokers. Accounting and Business Research, vol. 30, no. 1 (VVinter):3-16.

12. Capstaff, John. 2001. A Comparative Analysis of Earnings Forecasts in Century Books, London, 80

13. Das, S. and S. Saudagaran. 1998. Accuracy, Bias, and Dispersion in Analysts Earnings Forecasts: The Case of Cross-Listed Foreign Firms. Journal of International Financial Management and Accounting. 9: 16-33.

14. Das, S. and S. Saudagaran. 2002. Accuracy of Analysts Earnings Forecasts: A Comparison of Non-US Cross-Listed Firms and US Multinationals. Journal of International Accounting Research. 1:61-74.

15. Das, Somnath, Carolyn B.Levine, and K. Sivaramakrishnan. 1998. Earnings Predictability and Bias in .Analysts' Forecasts. Accounting Review, vol. 73, no. 2 (April):277-294.

16. Davis-Friday, P., and N. Rueschhoff. International Accounting Standards Versus U.S. GAAP: How Do They Compare? Working paper, University of Notre Dame, 1998.

17. De Bondt, W.F.M., and R.H. Thaler. 1991. Do Security Analysts Overreact? American Economic Review Papers and Proceedings, vol.80, no. 2(May):52-57.

18. De Bondt, Werner, and William P. Forbes. 1999, Herding in Analyst Earnings Forecasts: Evidence from tlie United Kingdom. European Financial Management, vol. 5, no. 2:1-13

19. De Vires, Manfred Kets, Shekshnia, Stanislav, Korotov, Konstantin, and Florent-Treacy, Elizabeth, the New Global Russian Business Leaders: Lessons from a Decade of Transition

20. Dowen, R,J. 1996. Analyst Reaction to Negative Farnings for Large Well-Known Firms. Journal of Portfolio Management, vol. 23, no. 1 (Fall):49-55.

21. Dreman, D.N., and M.A. Berry. 1995, Analyst Forecasting Errors and Their Implications for Security Analysis, Financial Analysts Journal, vol. 51, no, 3 (May/June):30-41.

22. Easterwood,J.C., and S.R. Nutt. 1999. Inefficiency in Analysts' Earnings Forecasts: Systematic Misreaction or Systematic Optimism? Journal of Finance, vol. 56, no. 5 (October):1777-97.

23. Elloitt, J., and D. Philbrick. 1990. Accounting Changes and Earnings Predictability. The Accounting Review (January): 157-74.

24. Financial Accounting Standards Board (FASB). 1996. The IASC-U.S. Comparison Project: A Report on the Similarities and Differences Between IASC Standards and U.S. GAAP.

25. Francis, J., and D. Phiibrick. 1993. Analysts' Decisions as Products of a Multi-Task Environment, Journal of Accounting Research, vol, 31, no, 2 (Autumn):143-163.

26. Gannon, Martin (and Associates) 1994, Understanding Global Cultures, Sage Publications: Thousand Oaks, California, 129

27. Goldman, Marshall I., The Piratization of Russia: Russian Reform Goes Awry, Routledge, London, 31

28. Gratchev, Mikhail, Nikolai Rogovsky, and Boris Ratitski, Leadership and Culture in Russia. Working Paper, Moscow Institute of World Economy and International Relations, 22

29. Gustafson, Thane 1999, Capitalism-Russian Style, Cambridge University Press: Cambridge, England, 173

30. Harper, Timothy, Moscow Madness: Crime Corruption, And One Man's Pusuit of Profit In The New Russia, 1999 McGraw Hill, New York, 62

31. Hope, O.K. 2003. Disclosure Practices, Enforcement of Accounting Standards, and Analyst's Forecast Accuracy: An International Study. Journal of Accounting Research. 41 (2): 235-273.

32. Huberts, Lex, and Russell Fuller. 1995. Predictability Bias in the U.S. Equity Market. Financial Analysts Journal, vol. 51, no. 2 (March/April):12-28.

33. Joos, P., and M. Lang. The Effects of Accounting Diversity: Evidence from the European Community. Journal of Accounting Research (Supplement 1994): 141-68.

34. Joyce, John 1984, The Old Russian Legacy, Foreign Policy, no. 55. (summer) 132-153

35. Kross, W., B.T. Ro, and D. Schroeder. 1990. Earnings Expectations: The Analyst's Information Advantage. The Accounting Review. 65: 461-476.

36. Lang, M., and R. Lundholm. 1996. Corporate Disclosure Policy and Analyst Behavior. The Accounting Review. 71: 467-492. 
37. Lang, M., K.V. Lins, and D. Miller. 2003. ADRs, Analysts, and Accuracy: Does Cross-Listing in the U.S. Improve a Firm's Information Environment and Increase Firm Value? Journal of Accounting Research. 41 (3): $317-345$.

38. Lebaron, Dean, and Carpenter, Donna. 2002. Mao, Marx, and The Market. John Wiley \& Sons.

39. Locus, Mark 2001, American Optimism Meets Slavic Fatalism: reflections on Social Categories and Political Power. Journal of Mundane Behavior, vol. 2, no. 3, 1-20

40. Pew Global Attitude Project 2006, China's Optimism. Pew Global Attitude Projest. November 16, 2006

41. Pourjalali, H., and G. Meek, 1995, Accounting and Culture: The Case of Iran, Advances in Accounting in Emerging Economies 3, pp. 3-17.

42. Public Opinion Foundation, Do Russians Feel Economic Growth. http://english.fom.ru/highlights/2069.html, July 24, 2007

43. Revsine, L. D.W.Collins, and W.B. Johnson. 2005. Financial Reporting and Analysis. 2nd Edition. Upper Saddle River, NJ. Prentice Hall.

44. Shiller, Robert J, Boycko, Maxim, and Korobov, Vladimir, Popular Attitudes Toward Free Markets: The Soviet Union and the United States Compared, The American Economic Review 1991 Vol. 81 No. 3, 385

45. Sinha, P., L.D. Brown, and S. Das. 1997. A Re-Examination of Financial Analysts' Differential Earnings Forecast Accuracy. Contemporary Accounting Research. vol. 14, no. 1 (Spring);1-42.

46. Smith, B. Mark, A History of the Global Stock Market, the University of Chicago Press, Chicago, Illinois, 295

47. Stewart, Wayne, JoAnn Carland, James Carland, Warren Watson, and Robert Sweo 2003, Entrepreneurial Dispositions and Goal Orientations: A Comparative Exploration of United States and Russian

Entrepreneurs. Journal of Small Business Management, vol. 41, no. 1. 40

48. Young, James, Moscow Mule: Russia - A Journey of A Thousand Years Going Where? 1996 


\section{NOTES}

